\title{
Psychosocial Adjustment to Cardiovascular Diseases and Spiritual Well-Being in Iranian Patients
}

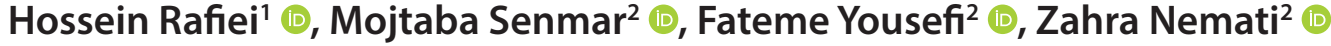 \\ 'Social Determinants of Health Research Center, Research Institute for Prevention of Non-Communicable Diseases, Qazvin \\ University of Medical Sciences, Qazvin, Iran \\ ${ }^{2}$ Student Research Committee, Qazvin University of Medical Sciences, Qazvin, Iran
}

\begin{abstract}
Objective: In this study, we assessed psychosocial adjustment in patients with cardiovascular diseases and its relationship with spiritual well-being.

Methods: This descriptive analytic study was performed in 2018 in Qazvin, Iran. The subjects were 150 patients who were admitted to the cardiac ward of a teaching hospital. Data were collected using a background variables checklist developed by the researchers and two standard questionnaires of Psychosocial Adjustment to Illness Scale and Ellison-Paloutzian Spiritual Well-Being Scale.

Results: The final score of psychosocial adjustment to cardiovascular diseases was 62.78 \pm 6.8 (range 48-83), indicating a moderate level of psychosocial adjustment to cardiovascular diseases. The mean score of psychosocial adjustment to cardiovascular diseases was significantly higher in women than in men $(p=0.03)$. In this study, the mean of overall spiritual well-being was 74.93 indicating a moderate level of spiritual well-being. The mean of overall spiritual well-being was significantly higher in women than in men $(p=0.001)$. The results showed a significant negative relationship between the participants' psychosocial adjustment to cardiovascular diseases and spiritual well-being $(r r=-0.21, p=0.01)$.
\end{abstract}

Conclusion: Findings from this study revealed that patients with cardiovascular diseases have a poor level of psychosocial adjustment. Patients with higher level of spiritual well-being reported better psychosocial adjustment.

Keywords: Adaptation, psychological, social adjustment, heart diseases, spirituality, nursing care

\section{İranlı Hastalarda Kardiyovasküler Hastalıklara Psikososyal Uyum ve Ruhsal İyilik Hali}

Özet

Amaç: Bu çalışmada kardiyovasküler hastalığı olan hastalarda psikososyal uyumu ve bunun ruhsal iyilik hali ile ilişkisini değerlendirdik.

Yöntemler: Bu tanımlayıcı analitik çalışma 2018 yılında İran'ın Kazvin kentinde gerçekleştirilmiştir. Denekler, bir eğitim hastanesinin kardiyoloji servisine kabul edilen 150 hastaydı. Veriler, araştırmacılar tarafından geliştirilen bir arka plan değişkenleri kontrol listesi ve Hastalığa Psikososyal Uyum Ölçeği ve Ellison-Paloutzian Manevi İyi Oluş Ölçeği'nin iki standart anketi kullanılarak toplanmıştır.

Bulgular: Kardiyovasküler hastalıklara psikososyal uyumun nihai skoru 62.78 \pm 6.8 (aralık=48-83) olup kardiyovasküler hastaIıklara orta düzeyde psikososyal uyumu göstermektedir. Kadınlarda kardiyovasküler hastalıklara psikososyal uyum ortalama

Correspondence (iletişim): Hossein Rafiei. Social Determinants of Health Research Center, Research Institute for Prevention of Non-Communicable Diseases, Qazvin University of Medical Sciences, Qazvin, Iran

Phone (Telefon): 989359399825 E-mail (E-Posta): hosseinr21@gmail.com

Submitted Date (Başvuru Tarihi): 29.07.2020 Accepted Date (Kabul Tarihi): 02.06 .2021

oCopyright 2021 by Turkish Society of Cardiology - Available online at www.khd.tkd.org.tr

OPEN ACCESS This work is licensed under a Creative Commons Attribution-NonCommercial 4.0 International License. 
skoru erkeklere göre anlamlı olarak daha yüksekti ( $p=0.03)$. Bu çalışmada genel ruhsal iyilik hali ortalamasının 74.93 olması orta düzeyde ruhsal iyilik halini ifade etmektedir. Genel ruhsal iyilik halinin ortalaması kadınlarda erkeklere göre anlamlı olarak daha yüksekti ( $p=0.001)$. Sonuçlar, katılımcıların kardiyovasküler hastalıklara psikososyal uyumu ile ruhsal iyilik hali arasında anlamlı bir negatif ilişki olduğunu gösterdi ( $r r=-0.21, p=0.01)$.

Sonuç: Bulgular, kardiyovasküler hastalığı olan hastaların psikososyal uyum düzeylerinin düşük olduğunu ortaya koymuştur. Ruhsal iyilik hali düzeyi daha yüksek olan hastalar daha iyi psikososyal uyum bildirdiler.

Anahtar sözcükler: Adaptasyon, psikolojik, sosyal uyum, kalp hastalıkları, maneviyat, hemşirelik bakımı

Cite this article as: Rafiei H, Senmar M, Yousefi F, Nemati Z. Psychosocial Adjustment to Cardiovascular Diseases and Spiritual Well-Being in Iranian Patients. Turk J Cardiovasc Nurs 2021;12(28):75-80.

C ardiovascular diseases are chronic and common throughout the world. ${ }^{[1,2]}$ They cause 17.7 million deaths in the world annually, which is one-third of all deaths. ${ }^{[3]}$ This rate is considerably higher in Iran, and it was reported to be nearly $50 \%$ in some studies. ${ }^{[4]}$

Many patients with cardiovascular diseases experience anxiety, depression, and a feeling of sorrow and loss. ${ }^{[5]}$ Cardiovascular diseases are chronic and affect all dimensions of life over the years. ${ }^{[6]}$ Lack of proper adjustment to a new condition can cause several problems in patients with cardiac illness, such as increased rate of psychological disorders and decreased functional activity. ${ }^{[7]}$

Therefore, patients with cardiovascular diseases need to adapt to their new condition appropriately. ${ }^{[8]}$ Previous studies have shown that patients with cardiovascular diseases face numerous problems in adjustment to the disease. In a study, Khalilzade et al. ${ }^{[9]}$ examined adjustment to cardiac failure among the patients living with the problems of this disease. In this study, 60 patients with heart failure were examined. The results showed that a high percentage of patients with heart failure have poor adjustment to their illness.

Spiritual well-being is an important dimension of health, which integrates relationship between inner forces. It is characterized by stability in life, peace, fitness and harmony, and a feeling of connection with God. ${ }^{[10]}$ According to Palutzian and Ellison, ${ }^{[10]}$ spiritual well-being has vertical and horizontal dimensions [10]. The vertical dimension includes a healthy feeling regarding God (religious), and the horizontal dimension is a feeling of satisfaction and purposefulness in life (existential health). ${ }^{[1]}$ Indeed, spiritual well-being is a feeling of harmonic relationship between self, others, nature, and a higher power, which is provided by a dynamic growth process and results in the perception of meaning and ultimate goal of life. In the recent years, there have been significant investigation and discussion about spiritual well-being and its effects on life in patients with cardiovascular diseases. In a study, Gök Metin and Helvacl $^{[12]}$ examined the relationship between spiritual health and quality of life and psychological problems among patients with heart failure in Turkey. The results showed a reverse relationship between spiritual health and psychological problems in this group of patients. ${ }^{[12]}$

Spiritual well-being and spirituality can affect psychosocial adjustment to illness (PSAl) among the patients. ${ }^{[13]}$ However, few studies have been conducted on spiritual health and its relationship with PSAI in patients with cardiovascular diseases. Patients with cardiovascular diseases may experience different physical and psychological symptoms than other patients. Therefore, a study on PSAI in patients with cardiovascular diseases and its related factors is necessary.

This study had two main aims: 1) to examine PSAI among patients with cardiovascular diseases and 2) the relationship between PSAI and level of spiritual well-being.

\section{Materials and Methods}

\section{Sample}

This was a descriptive analytic study conducted in 2018 in Qazvin, Iran. The participants included 150 male and female patients who were admitted to the cardiac ward of a teaching hospital in Iran. They were selected by convenience sampling. The inclusion criteria were having cardiac disease, age over 18, and agreeing to participate in the study. Patients with serious conditions according to their medical report, such as those in the acute phase of acute coronary syndrome (ACS) or patients who needed emergency cardiac surgery and patients who were unable to respond questions were excluded from the study.

Using the below formula for sample size and considering $a=0.05, \beta=0.10$, and $r=0.3$, the minimum sample size was determined to be 99 cardiac patients. Because of the availability of more patients in our hospital, we finally entered 120 patients into the study.

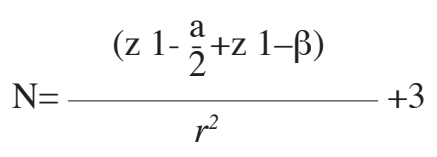

\section{Data Collection Methods and Tools}

Two researchers collected the data throughout the study. Following obtaining necessary approval and coordination with head nurses, the researchers visited the wards on spe- 
cific times during the day. Before providing the questionnaire to patients, the objective of the study was restated to them. Patients were asked to complete the questionnaires in one hour and return them to the researcher. The researchers visited the wards and answered all their possible questions.

Data were collected using a background variables checklist developed by the researchers, which included age, sex, and marital and economic status. We also used two standard questionnaires of PSAI Scale and Ellison-Palutzian Spiritual Well-Being Scale.

The PSAI scale: The PSAI scale was developed by Leonardo Derogatis to assess PSAI in patients with chronic diseases. ${ }^{[14]}$ This questionnaire consists of 46 questions and seven subscales. Its domains are health care orientation, vocational environment, domestic environment, sexual relationships, extended family relationship, social environment, and psychological distress. This questionnaire is marked on a fourpoint Likert scale (0-3). The sum of scores of the 46 questions range from 0 to 138 . Final scores of less than 35 indicate a high level of PSAl, score between 35 to 51 indicate a fair level of PSAl, and scores of more than 51 indicate low level of PSAI. ${ }^{[14]}$

In this study, the Persian version of this questionnaire was used; Feghhi et al.. ${ }^{[15]}$ approved its translation, validity, and reliability.

The Ellison-Paloutzian Spiritual Well-Being Scale: This questionnaire consists of 20 questions. It assesses spiritual well-being in two dimensions of religious well-being and existential well-being. The score of each dimension ranges from 10-60, and the score of overall spiritual wellbeing ranges between 20 and 120. Responses to each question range from 1 to 6 . A higher score on this scale showed a higher level of spiritual well-being (scoring not ranged). The Persian version of this questionnaire has appropriate validity and reliability and has been frequently used in Iranian patients. ${ }^{[16-18]}$

\section{Evaluation of Research Data}

Analysis of the gathered data was performed with the Statistical Package for Social Sciences version 16 (SPSS Inc.; Chicago, IL, USA). Given the normal distribution of data according to the Kolmogorov-Smirnov test ( $p$ values $>0.05$ ), parametric tests including Pearson correlation coefficient test, one sample student $\mathrm{t}$-test, and analysis of variance were used for analysis. The level of significance was considered at 0.05 in all tests, except the Kolmogorov-Smirnov test.

\section{Ethics}

The Helsinki Declaration code of ethics in human study was considered during all stages of the study. Ethical approval was obtained from the ethics committee of Qazvin University of Medical Science QUMS (ethical code: IR.QUMS.REC.1395.139) in 2017. The consent form was read and signed by all the patients after they were provided with the necessary information regarding the methods and objective of the study.

\section{Results}

The mean age of the patients was $55.4 \pm 13.6$ years. Of the 150 patients, $50 \%$ were men, $75 \%$ were married, and $62 \%$ had a lower diploma. In terms of economic status, most participants had a relatively appropriate economic status.

\section{The PSAI}

The mean score of total PSAI in the patients investigated was $62.78 \pm 6.8$ (range 48-83). The mean scores were significantly higher in men than in women. Table 1 shows PSAI scores and their relationship with patients' demographic characteristics in detail.

\section{Spiritual Wellbeing}

In this study, the mean score of total spiritual well-being and its dimensions of religious and existential well-being was $74.93,35.97$, and 39.07, respectively. Table 1 shows the spiritual well-being scores and their relationship with the patients' demographic characteristics in detail.

\section{Relationship Between PSAI and Spiritual Well-being in Patients with Cardiovascular Diseases}

Findings showed a negative relationship between mean PSAl scores and mean spiritual well-being scores in patients with cardiovascular diseases who were investigated in this study ( $r r=-0.21, p=0.01)$.

\begin{tabular}{|c|c|c|c|c|c|}
\hline \multicolumn{2}{|l|}{ Demographics } & \multicolumn{2}{|c|}{ PSAI total score } & \multicolumn{2}{|c|}{ Total spiritual well-being } \\
\hline \multirow[t]{2}{*}{ Sex } & Male & $63.9 \pm 7.7$ & $p=0.03$ & $68.10 \pm 10.1$ & $p=0.001$ \\
\hline & Female & $61.4 \pm 5.7$ & & $81.99 \pm 5.1$ & \\
\hline \multirow[t]{2}{*}{ Marital status } & Married & $62.9 \pm 3.1$ & $p=0.714$ & $75.12 \pm 3.7$ & $\mathrm{p}=0.296$ \\
\hline & Single & $61.8 \pm 2.9$ & & $73.9 \pm 2.6$ & \\
\hline \multirow[t]{3}{*}{ Economic status } & Poor & $62.1 \pm 2.4$ & $p=0.796$ & $75.9 \pm 7.2$ & $\mathrm{p}=0.02$ \\
\hline & Moderate & $61.9 \pm 7.2$ & & $73.1 \pm 1.8$ & \\
\hline & Good & $63.0 \pm 4.1$ & & $72.4 \pm 6.6$ & \\
\hline Age & $p=0.546$ & $p=0.362$ & & & \\
\hline
\end{tabular}




\section{Discussion}

In this study, we examined PSAI in a group of Iranian patients with cardiovascular diseases and its relationship with their level of spiritual health. The results showed that patients have a poor level of PSAl, and their sex affects it significantly. The results also showed that levels of spiritual well-being were higher in patients with better PSAI.

Adjustment is preserving a positive attitude to self and the universe despite physical problems. ${ }^{[8]}$ The results of our study showed that patients with cardiovascular diseases have problems in PSAI. Our literature review showed a few studies that examined the PSAI among the patients with cardiovascular disease. Karatas and Bostanoglu ${ }^{[19]}$ in Turkey examined this topic in 250 patients with cardiovascular diseases. Similar to the results of our study, their findings showed that this group of patients had poor adjustment to illness. In another study conducted in Iran, Hekari and Mohammadzadeh ${ }^{[20]}$ examined the level of adjustment in women with coronary artery diseases based on Roy's nursing theory. The results showed that women had moderate adjustment in dimensions of physiologic, self-concept, and role function and poor adjustment in the interdependence dimension, which is different from the findings of our study. This difference could be related to the difference in samples of the two studies. Hekari and Mohammadzadeh $^{[20]}$ examined adjustment in women only. In addition, the questionnaires in our study for assessing PSAI were different from the questionnaires in study by Hekari and Mohammadzadeh. ${ }^{[20]}$ Patients with cardiovascular diseases face numerous physical, psychological, and environmental challenges, ${ }^{[21]}$ which occur more frequently in developing countries. Although PSAI is important in patients with cardiovascular diseases, few studies have been conducted on effective interventions for increasing psychosocial adjustment. However, among other groups of patients such as those on hemodialysis or with cancer, studies have shown that use of nursing theories such as the Roy's nursing theory is useful. ${ }^{[22-24]}$

According to the findings of this study, the spiritual dimension of life should be considered to improve PSAI in patients with cardiovascular diseases. An increase in the level of spiritual well-being results in an increase in PSAI. Although the relationship between PSAI and spiritual health has not been investigated in this group of patients, the results of other studies conducted on patients with other conditions are consistent with this study. ${ }^{[25,26]}$ In a study, Aghaeipour et al. ${ }^{[27]}$ examined the relationship between spiritual well-being and anxiety in 384 older patients with heart failure. They used the Ellison-Palutzian spiritual well-being questionnaire and Beck anxiety scale. The results showed that older patients with heart failure who have a higher spiritual health experience less anxiety. Indeed, a higher level of spiritual health is a protective factor against anxiety in these patients. ${ }^{[27]}$ In another study, Bekelman et al. ${ }^{[28]}$ examined the relationship between spiritual health and depression in a group of patients with cardiovascular diseases. The results showed that a higher spiritual health decreased depression in these patients. Spirituality and spiritual health have been considered in healthcare in the past. ${ }^{[29]}$ Indeed, spirituality is an important source in adjustment to stressful situations, particularly health-related issues. ${ }^{[30]}$ It gives people identity, satisfaction, pleasure, love, respect, positive attitude, peace, inner harmony, and a purpose in life. ${ }^{[31]}$ Patients with cardiovascular diseases have used spirituality as a mechanism for better adjustment to illness, and cardiac nurses should pay attention to and improve this aspect.

The results of our study also revealed that women have better PSAI than men. Gautam and Poudel ${ }^{[32]}$ also reported similar findings. They reported that women with colorectal cancer have better adjustment than men with the same illness. ${ }^{[32]}$ In another study in Portugal, researchers examined PSAI in adolescents and young adults with congenital heart disease and reported that female patients have a poor level of PSAI, which is different from the findings of this study. This difference could be related to the difference in samples of the two studies. ${ }^{[33]}$ The sample of the Portugal study were younger than the sample in our study (mean age of 18.7 versus 55.4 years). In addition, it appears that women use spirituality more than men as a coping strategy for adjustment to illness because they reported a higher level of spirituality in women than in men in this study.

\section{Limitations}

Our study performed in one center and generability of finding affected. Also all patients who participate in our study were Muslim that should be considered when using finding.

\section{Conclusion}

The results of our study revealed that patients with cardiovascular diseases have a poor level of PSAl, which has a significant relationship with their spiritual well-being. The results of our study could be used to enhance healthcare in this group of patients. Given few studies on this topic, it is recommended that further studies be carried out in other societies. It is also recommended to examine the relationship of spiritual well-being with other dimensions of life in patients with cardiovascular diseases, including the psychological situation and quality of life. 
Ethics Committee Approval: Ethics committee of Qazvin University of Medical Science (Approval Date: 2017; Approval Number: IR.QUMS.REC.1395.139).

Peer-review: Externally peer-reviewed.

Authorship Contributions: Concept: H.R., M.S.; Design: H.R., M.S., F.Y., Z.N.; Supervision: H.R.; Materials: H.R., M.S., F.Y., Z.N.; Data Collection and/or Processing: M.S., F.Y., Z.N.; Analysis and/ or Interpretation: H.R., M.S.; Literature Search: H.R., M.S., F.Y., Z.N.; Writing: H.R., M.S., F.Y., Z.N.; Critical Revision: H.R., M.S.

Conflict of Interest: The authors have no conflict of interest to declare.

Financial Disclosure: The authors declared that this study has received no financial support.

\section{References}

1. Roth GA, Mensah GA, Johnson CO, Addolorato G, Ammirati E, Baddour LM, et al. global burden of cardiovascular diseases and risk factors, 1990-2019: update from the GBD 2019 study. J Am Coll Cardiol 2020;76:2982-3021.

2. Givi M, Sarrafzadegan N, Garakyaraghi M, Yadegarfar G, Sadeghi M, Khosravi A, et al. Persian Registry Of cardioVascular diseasE (PROVE): design and methodology. ARYA Atheroscler 2017;13:236-44.

3. World Health Organisation fact sheet for cardiovascular-diseases. Available from: https://www.who.int/en/news-room/ fact-sheets/detail/cardiovascular-diseases-(cvds).

4. Hatmi ZN, Tahvildari S, Gafarzadeh Motlag A, Sabouri Kashani A. Prevalence of coronary artery disease risk factors in Iran: a population based survey. BMC Cardiovasc Disord 2007;7:32. [Crossref]

5. Higgins RO, Murphy BM, Nicholas A, Worcester MU, Lindner $\mathrm{H}$. Emotional and adjustment issues faced by cardiac patients seen in clinical practice: a qualitative survey of experienced clinicians. J Cardiopulm Rehabil Prev 2007;27(5):2917. [Crossref]

6. Imani A, Gharibi F, Dadashi O, Najafi M, Mirbagheri SM. Analysis of cardiovascular diseases costs and their effective factors in Tabriz hospitalized patients, 2015. Jundishapur J Health Sci 2016;8(2):e32503.

7. McLaughlin TJ, Aupont O, Bambauer KZ, Stone P, Mullan MG, Colagiovanni J, et al. Improving psychologic adjustment to chronic illness in cardiac patients. The role of depression and anxiety. J Gen Intern Med 2005;20(12):1084-90. [Crossref]

8. Sahranavard S, Ahadi H, Taghdisi MH, Kazemi T, Kraskian A. The role of psychological factors on the psychological and social adjustment through the mediation of ischemic heart disease hypertension. Iranian Journal of Health Education and Health Promotion 2017;5(2):139-46. [Crossref]

9. Khalilzadeh H, Nanbakhsh J, Yaghoubi M. Chronic heart failure patient's adjustment to disease problem in Taleghani educational center in Urmia. Journal of Nursing and Midwifery Urmia University of Medical Sciences 2006;4(4):154-60.

10. Paloutzian RF, Ellison CW. Manual for the Spiritual Well-being Scale. New York, NY: Life Advance, Nyack; 1991.

11. Zeighami Mohammadi S, Tajvidi M, Ghazizadeh S. The relationship between spiritual well-being with quality of life and mental health of young adults with beta-thalassemia major. The Scientific Journal of Iranian Blood Transfusion Organization 2014;11(2):147-54.

12. Gök Metin $Z$, Helvacı A. The correlation between quality of life, depression, anxiety, stress, and spiritual well-being in patients with heart failure and family caregivers. Turk J Cardiovasc Nurs 2020;11(25):60-70.

13. Jani S, Molaee M, Jangi S, Pouresmali A. Effectiveness of cognitive therapy based on religious believes on death anxiety, social adjustment and subjective well-being in the cancer patients. Journal of llam University of Medical Sciences 2014; 22(5):94-103.

14. Derogatis LR. The psychosocial adjustment to illness scale (PAIS). J Psychosom Res 1968;30(1):77-91. [Crossref]

15. Feghhi H, Saadatjoo A, Dastjerdi R. Psychosocial adaptation in patients with type 2 diabetes referring to Diabetes Research Center of Birjand in 2013. Modern Care Journal 2014;10(4):249-56.

16. Biglari Abhari M, Fisher JW, Kheiltash A, Nojomi M. Validation of the Persian version of Spiritual Well-Being Questionnaires. Iran J Med Sci 2018;43(3):276-85.

17. Rafiei H, Naseh L, Hoseinabadi-Farahani MJ, Aghaei S, Hosseinzadeh K, Razaghpoor A, et al. Spiritual wellbeing and quality of life in stoma patients. Gastrointestinal Nursing 2018;16(5):27-31. [Crossref]

18. Senmar M, Hasannia E, Moeinoddin A, Lotfi S, Hamedi F, Habibi $M$, et al. Psychosocial adjustment to illness and its relationship with spiritual wellbeing in Iranian cancer patients. Int J Chronic Dis 2020;2020:5742569.

19. Karatas T, Bostanoglu H. Perceived social support and psychosocial adjustment in patients with coronary heart disease. Int J Nurs Pract 2017;23(4):e12558.

20. Hekari D, Mohammadzadeh R. The assessment of adaptation rate of coronary artery disease female patients according to quadruple aspects of physiologic, self perception, role playing and independence/dependence in Tabriz, 1386-87. Medical Sciences Journal 2008;18(3):187-93.

21. Kim GB. Psychosocial adjustment and quality of life of adolescents and adults with congenital heart disease. Korean J Pediatr 2014;57(6):257-63. [Crossref]

22. Afrasiabifar A, Karimi Z, Hassani P. Roy's adaptation model-based patient education for promoting the adaptation of hemodialysis patients. Iran Red Crescent Med J 2013;15(7):566-72. [Crossref]

23. Kacaroglu Vicdan A, Gulseven Karabacak B. Effect of treatment education based on the Roy adaptation model on adjustment of hemodialysis patients. Clin Nurse Spec 2016;30(4):E1-13.

24. Shahed S, Vanaki Z, Tahmasebi M. Effect of an educational-supportive program based on Roy Adaptation model on marital satisfaction in mastectomy patients receiving chemotherapy. Evidence Based Care 2016;6(1):71-8.

25. Li CC, Rew L, Hwang SL. The relationship between spiritual well-being and psychosocial adjustment in Taiwanese patients with colorectal cancer and a colostomy. J Wound Ostomy Continence Nurs 2012;39(2):161-9. [Crossref]

26. Tanyi RA, Werner JS. Adjustment, spirituality, and health in women on hemodialysis. Clin Nurs Res 2003;12(3):229-45. [Crossref] 
27. Aghaeipour Amshal E, Rejeh N, Heravi-Karimooi M, Tadrisi D. Relationship between spiritual wellbeing with anxiety in elderly patients with chronic heart failure who referred to allocated hospitals in Tehran city (2015). Iranian Journal of Nursing Research 2016;10(4):145-54.

28. Bekelman DB, Dy SM, Becker DM, Wittstein IS, Hendricks DE, Yamashita TE, et al. Spiritual well-being and depression in patients with heart failure. J Gen Intern Med 2007;22(4):470-7. [Crossref]

29. Jaberi A, Momennasab M, Yektatalab S, Ebadi A, Cheraghi MA. Spiritual health: a concept analysis. J Relig Health 2019;58(5):1537-60. [Crossref]

30. Kadivar M, Seyed Fatemi N, Shojaei Jeshvaghani S, Cheraghi MA, Haqqani H. Exploring the relationship between spiritual well-being and stress and coping strategies in the mothers of infants hospitalized in the neonatal intensive care units. Daneshvar Medicine 2015;22(118):67-76.
31. Dehbashi F, Sabzevari S, Tirgari B. The relationship between spiritual well-being and hope in Hemodialysis patients referring to the Khatam Anbiya hospital in Zahedan 2013-2014. Medical Ethics Journal 2015;9(30):21.

32. Gautam S, Poudel A. Effect of gender on psychosocial adjustment of colorectal cancer survivors with ostomy. J Gastrointest Oncol 2016;7(6):938-45. [Crossref]

33. Coelho R, Teixeira F, Silva AM, Vaz C, Vieira D, Proença C, et al. Ajustamento psicossocial, morbilidade psiquiátrica e qualidade de vida em adolescentes e jovens adultos com cardiopatias congénitas [Psychosocial adjustment, psychiatric morbidity and quality of life in adolescents and young adults with congenital heart disease]. Rev Port Cardiol 2013;32(9):657-64. 